\title{
ECONOMIC DEVELOPMENT AS AN EMPIRICAL CONCEPT ${ }^{1}$
}

\author{
David W. Rasmussen*
}

Economic development must be the most abused term in social science. It is used to mean many different things; it describes both a state and a myriad of processes. Development is a state to be achieved since developed countries have a per capita income in excess of $\$ 1500$; "lesser" developed counties do not. Development is also widely viewed as a process. Many scholars have emphasized that development is distinct from the concept of growth, but careful usage of these terms is not common practice. Flammang (1979) reports nine different ways of distinguishing between growth and development, one of which is not bothering to define either term.

One approach is to endow development with important normative characteristics, so in contrast with growth this term implies something "better". Sen (1983) takes this tack. In his lexicon growth refers to increased national output while development is "concerned with what people can or cannot do, e.g., whether they live long, escape avoidable morbidity, be well nourished, be able to read and write...and so forth." (p. 754) The difficulty with this distinction is that development involves a notion of "good" policy and does not focus on the dynamics of economic change with which the term is most often associated.

A consensus view offered by Flammang (1979) is that "economic growth is simple increase, implying more of the same, while economic development is a process of structural change, implying something different if not something more." (50)

Emphasizing the process of structural change, development involves ongoing change in both low income and affluent countries. This definition also has appeal because of its explicit recognition that development is a two edged sword; structural change can lead to either increasing or decreasing welfare in a population.

In this paper we explore a positive definition of development that has empirical content. Obviously we cannot measure development per se since it involves a host of institutional changes, demographic shifts, technical change, and changes in international economic relations that are too varied and heterogeneous to measure in a simple way. But we can observe whether development has occured by investigating long term changes in aggregate

*Professor of Economics and Policy Sciences, Florida State University, Tallahassee, Florida. measures of economic performance and the distribution of income.

Ignoring important measurement problems that will be explored below, changes in well being in an economy can be captured with two variables: the rate of economic growth and changes in the income distribution. Development is defined to be structural changes that change the a) long term rate of economic growth and/or b) size distribution of income. ${ }^{2}$ The length of time during which the new long term rate of growth and/or the income distribution is maintained is called the period of development. ${ }^{3}$ It is important to remember that structural forces influencing these variables may not have been at work in the same period the development is observed.

The growth and income distribution variables capture much of what we customarily refer to as development in Third World nations. At the outset of the modernization process economic development facilitates economic growth. Traditional societies must undergo profound institutional change in order to pave the way for higher growth of output. The conditions for achieving what Rostow (1961) called the "take-off" to modernization are not just economic - they are also technical, cultural, sociological, psychological, and political. Although measurement of these factors is problematic, we can measure the consequences of development, a change in the long term rate of growth. Kuznets (1955) argued that development is expected to be accompanied by changes in the distribution of income, our second variable of interest that is subject to empirical observation. Thus the definition of development offered here is consistent with much of the conventional thinking done in the economics of developing countries. ${ }^{4}$

Of more immediate interest, however, is the application of this notion of development to advanced industrial economies, and more particularly, to contemporary America. Amos (1989) and Flammang (1989) make explicit their intention to discuss the idea of development as it applies to these economies. Flammang's discussion of structural change in the American economy makes explicit that this advanced economy can be strongly affected by the development process. He explores the 1920 s and the subsequent Great Depression from this perspective; he argues a more recent example can be found in trend toward deregulation that followed the apparent stagnation of the 1970s. Amos is ambitious in his attempt to tie together 
regional economic growth (via growth pole theory) and long waves of economic activity. He succeeds in emphasizing that the long term development process is crucial to the understanding of what happens in a modern economy. Malazia (1989) shares this view since he argues that forecasts of regional growth could be improved if the models used for this purpose were rooted in the concept of economic development.

\section{Evidence of American Economic Development}

Our first indicator of development is change in the long term growth path of GNP, here measured by the growth of output per worker. ${ }^{5}$ That U.S. annual labor productivity growth has fallen for much of the last two decades is widely accepted. Annual productivity growth was 2.74 percent from 1950 to $1964,1.84$ percent from 1965 to $1973, .55$ for the $1973-80$ period and 1.34 from 1980 to 1987.6

Some explanations of this apparent productivity trend focus on rapid labor force growth that lowers the capital labor ratio; others blame slow growth on the rising service sector that is presumed to be less technologically progressive than manufacturing, greater government regulation and declining expenditures on civilian research and development. Rising energy prices are sometimes labeled the culprit, but the trend apparently predates the first oil shock of 1974. Some factors, such as rapid labor force growth and oil shocks, are not long term and represent transitory (although extended in the case of the labor force growth rate) factors affecting productivity growth. Long term decline that can be construed as economic development would be the rising service sector and, perhaps, the expanding role of government in the economy. ${ }^{\text {? }}$

In order to ferret out long term decline from more transitory phenomenaaffecting growth of output per worker, we regress growth in U. S. labor productivity (PROD) for the years 1950 to 1987 on variables that control for the business cycle (the manufacturing capacity utilization in$\operatorname{dex}$ (CAPRATE) and the unemploymentrate(U)), adummy variable reflecting the years (1974 and 1979) in which there are oil shocks (OIL), the rate of growth of the civilian labor force (GLF), and a trend variable (TIME). The results are reported in regression 1.8

$$
\begin{gathered}
\text { PROD }=3.24+.10 \mathrm{U}+.22 \text { CAPRATE } \\
(4.08) \quad(.58) \quad(3.49) \\
-.61 \mathrm{GLF}-2.62 \mathrm{OIL}-.03 \mathrm{TREND} \\
(2.69) \quad(3.75) \quad(1.35)
\end{gathered}
$$

(t value)

$\mathrm{DW}=1.49$

$\mathrm{R}^{2}=.72$
Variables reflecting transitory factors - the rate of capacity utilization, oil shocks and growth of the labor force-are highly significant. The trend, intended to reflect the long term forces of development, is negative but not significantly different from zero. This measure suggests the U.S. has been in a single period of development during the years from 1950 to 1987.9

Of course, the national picture is obviously a mosaic of local trends in variables such as labor productivity or economic growth. Some regions or local economies are on the rise, others are in decline. But this indicator of development, the trend in the long term growth rate, can at least conceptually be used at the local, state or regional level. Flammang is right that niches in the economy are constantly changing; Malazia is correct in seeing that a region's capacity to adjust is a key ingredient in the development process.

Economic development, the structural transformation of an economy, can obviously be manifest in a changing distribution of economic well being. Aggregate data suggest this trend has been ongoing, with the proportion of national income going to the lowest quintile falling while that of the upper quintile is growing. Table One shows the gap between rich and poor is rising for many types of household. Family income at the bottom of the top quintile generally rose from 1979 to 1987 while that of the top earner in the bottom quintile fell, precipitiously in the case of young heads of household and single mothers with children.

Detailed studies of the distribution of earnings support these aggregate data, reporting that earnings among males are becoming more unequal. Since the distribution of family income is determined by family composition as well as income per worker, it seems preferable to investigate the trend in earnings of individuals. Henle and Ryscavage (1980) report Current Population Survey (CPS) data show increasing inequality among males over the 1958-1977 period. Blackburn and Bloom (1987) report similar results for 1967-1985. Dooley and Gottschalk (1984) showed that the variance of log annual earnings among males in the CPS rose 25 percent from 1967 to 1978 . In the latter study, about three-quarters of the variance of log annual earnings is within narrowly defined education/experience cells. Dooley and Gottschalk's weekly earnings data are more evenly distributed and show a 10 percent increase in the variance of $\log$ earnings from 1968 to 1977 . Not inconsistently, Medhoff (1984) has claimed there was no increase in hourly wage inequality from 1973 to 1984 . Changes in annual earnings inequality are affected by the variability in hours and weeks worked. Rasmussen and Zeman (1988) used the Panel Study of Income Dynamics and found a trend toward greater inequality among male heads of 
Table One

Growing Income Inequality, 1979-1987 Household Income*

\begin{tabular}{cccccc}
\hline \hline Household Type & \multicolumn{2}{c}{ Lowest Earner in Top 20\% } & & \multicolumn{2}{c}{ Highest Earner in Bottom 20\% } \\
\cline { 2 - 3 } & 1987 Income & Change Since 1979 & & 1987 Income & Change Since 1979 \\
\hline $\begin{array}{c}\text { Married Couples } \\
\text { w/children }\end{array}$ & 58,202 & $+12 \%$ & & 20,175 & $-3 \%$ \\
$\begin{array}{c}\text { Single Mothers } \\
\text { w/children } \\
\text { Heads of } \\
\text { Households } \\
\text { under 25 } \\
\text { Heads of } \\
\text { Households } \\
\text { over 65 }\end{array}$ & 22,407 & $+2 \%$ & & 3,954 & $-20 \%$ \\
\hline \hline
\end{tabular}

"Household income is adjusted for average family size.

Source: Congressional Budget Office, reported in Business Week, April 17, 1989.

household from 1967 to 1982 after controlling for the relative decline of the goods producing sector, demographic factors, and the business cycle.

Interpreting from a development perspective the apparent long term rise in income inequality is not without ambiguity. If the rising inequality is caused by corresponding changes in the distribution of human capital, this may not be an intractable long term problem. On the other hand, if the structure of employment has changed in a way that increased the returns to human capital relative to unskilled labor, the development process is obviously at work.

\section{Microeconomic Origins of Development}

Development in Third World countries is a process qualitatively different from that of modern industrial nations. In both circumstances development is accompanied by a changing rate of growth and/or a change in the distribution of income.

Development in Third World nations is essentially a macroeconomic phenomenon-the required institutional change must transform the society: markets created, saving used more effectively, investment increased, and population growth limited. The development problem is to generate growth by increasing the resource base and utilizing existing resources more efficiently. Social infrastructure that organizes and motivates the factors of production are at the core of the development problem in poor nations.

Development in advanced industrial countries such as the U.S. does not require such fundamental change since the institutional structure required for a high level of economic activity is already in place. Development in modern economies has its origins in microeconomic changes. The stimulus for economic transformation comes from changes in individual markets (through changing tastes, increasing international competition, and/or technological change) and institutional change which in turn influence the measured rate of economic growth and/or the distribution of income. Flammang (1989) hints at this when he argues that "niche filling" is primarily the growth process while "niche changing" is essentially structural change-economic development. ${ }^{10}$

We now turn to two examples of development in contemporary America. In each case there is a realignment of economic activity that can lead to changes in the rate of growth and/or the distribution of income. The examples are suggestive of the ways affluence and healthy technical change can transform the economy, often in unforseen ways. The case studies explored here are environmental protection and the medical sector. ${ }^{11}$

\section{Environmental protection}

If our national income accounts accurately reflected well being rather than Gross National Product and personal income, the use of changes in the rate of output growth and the income distribution might be satisfactory reflections of economic development. However, the socio-economic transformations we call development emerge in untidy ways. Consider, for example, the issue of environmental protection. When the U.S. had a relatively low level of per 
capita income, enviromental protection was not a national issue. One reason for this "issue" not being on the national agenda was the carrying capacity of the environment was not threatened as it would be in a more affluent period when toxic chemicals replaced biodegradable commodities. ${ }^{12}$ Another reason is the demand for environmental quality is probably elastic with respect to income.

Technical change and a larger economy combine to push to the limit the self cleansing capacity of the environment. Expenditures to improve and/or protect the environment raise the cost of output included in the national accounts and measured economic growth slows. Inadequate measures of output inevitably make it more difficult to identify changes in economic development. Rising expenditures for environmental pollution mean that the measured cost of goods rises.

To the extent this change is simply a matter of the consumption of more unmeasured output (environmental quality) relative to measured output (goods and services) this issue would simply be a measurement problem, i.e., measured GNP growth would fall while growth of "wellbeing" could be unchanged. However, since the cost of production of goods and service can rise with greater demand for environmental goods, foreign competitors not so constrained by environmental regulation will find it easier compete in all markets. U.S. firms will either lose market share or increase offshore investment. In either case, the rate of economic growth and the income distribution can change because of increasing environmental protection. ${ }^{13}$

\section{The Medical Sector}

Technological change in medicine is a powerful generator of institutional change. Changing capabilities of this sector have profound implications for the distribution of income. When medicine's comfort enhancing and life sustaining capacities were minimal, the distribution of income had little implication for the distribution of life expectancy. In America at the turn of this century rich and poor women alike died in childbirth; pneumonia took the high and low. Some medical innovation is truly democratic in that it is within reach of virtually all income classes-examples being penicillin and other so called miracle drugs. ${ }^{14}$ Other advances require sophisticated equipment and considerable human input, making them very expensive and impossible for most people to purchase without either great wealth or private insurance. Organ transplants and kidney dialysis are obvious examples.

Emergence of expensive life saving techniques changes the meaning of the income distribution; low income that once meant less material consumption now means less material consumption and higher avoidable morbidity and a shorter life span. Public policy, in considering access to medical advance, must explicitly consider changing the distribution of income because of technical change in this particular sector. Every modern economy has to some extent responded to this technological change by providing access to medical care to the lower reaches of the income distribution. ${ }^{15}$

Such technologically induced changes in the income distribution can have feedbackeffects on economic growth. The taxation required to pay for these transfers may raise marginal tax rates with adverse effects on work effort. Mancur Olson $(1982,1983)$ has argued that interest groups can create redistributive coalitions that inhibit economic growth. The political forces that are responsible for widespread access to medical care can be viewed in this way, although such policies seem to have widespread support. Whether viewed from the supply side perspective or as a form of economic arteriosclerois, it is possible for technological change in this particular sector to generate long term change in both the income distribution and the rate of economic growth.

\section{Development in a Sub National Context}

The notion of development in the work of Amos (1989) and Flammang (1989) can have specific empirical content when defined to be changes in the long term rate of growth and/or a change in the size distribution of income. These definitions can also be used to give empirical content to the term development in the regional context.

Regional growth sustains the rate of increase in income per capita and maintains the size distribution of income. As in the national setting, development changes these things. Local economies are affected by many of the factors enumerated by Malazia's (1989) effort to identify the sources of resilience in local economies. Resilience, the ability of a local economy to respond to changing niches is an obvious determinant of the long term rate of economic growth. Of course, subnational economies are to a major extent buffeted by trends in the national economy. In a study of state economic growth, Rasmussen and Zuehlke (1990) show that the most important determinant of state growth is the national business cycle. Yet local economies have comparative advantages with respect to changing economic niches. Emergence of high technology niches have been particularly favorable to areas such as Boston and Northern California. Conversely, the rise of foreign competitors was for a time difficult for much of the North East and North Central United States. Thus local economic development policy can potentially exploit either the strengths or the weaknesses of thenational economy, 
although growth of subnational economies is obviously constrained by the overall economic performance of the nation.

\section{Commentary}

Attempts to define precisely the complex development process inevitably leave discomforting loose ends. This effort is no exception. One that is particularly troublesome is the relationship between the concept of institutional change and economic development. The definition of development proffered here has the somewhat disconcerting implication that relatively dramatic changes in institutions, e.g., creation of credit cards and deregulation of banking, do not necessarily constitute economic development. Flammang (1989) argues that niche creation is development; here niche creation and filling are not viewed as part of the development process unless the new niche can foster a change in the long term long term rate of growth or change the distribution of income. ${ }^{16}$

Aside from its regional application, the concept of economic development has not played an important role in shaping the way economists understand advanced industrial economies. ${ }^{17}$ But from a policy perspective there is something liberating about focusing on the more basic economic trends rather than short term rates of economic growth. One senses that much of what passes for public debate in America is rooted in a hope that we can sustain a more rapid rate of growth so we can afford policy initiatives to confront crucial issues. A focus on economic development with its emphasis on long term changes in the rate of growth and the income distribution will perhaps provide a more realistic assessment of the promise and limitations of public policy.

\section{Notes}

'Professors Robert Flammang, James Cobbe and Larry Issacs contributed to this paper with comments on an earlier draft.

${ }^{2} \mathrm{~A}$ third factor, changes in the degree of socio-economic mobility, might be an important attribute of economic development that could be included in a more exrtensive investigation of this topic.

${ }^{3}$ During a period of development, it is possible that structural changes are required to sustain the long term rate of growth. These changes can be an important aspect of economic development which cannot be measured within the framework offered here.

"In the Third World context sustaining a growth rate may be a crucial aspect of the development problem. This is obviously a problem in more affluent countries as well. As development is defined here, institutional changes that sustains a growth rate lengthen the period of development but would not be defined as development. Since my intent here is to emphasize a positive definition of development, the definition must be limited to observable phenomena. This is not to lessen the importance of institutional and policy changes that sustain a rate of long term economic growth that otherwise would have diminished.

sOutput per hour of all persons is preferred to the altemative, multifactor productivity, for two reasons. First, labor productivity is more accurately measured than the more complex measure of multifactor productivity. Second, output per hour is appealing in that its growth is closely linked to the growth of personal income.

${ }^{6} \mathrm{Baumol}(1986$ ) argues that the $1950-64$ period was a unique period in U.S. economic history and that the subsequent experience is more typical of long term output growth per worker. The definition of "long term" is obviously important to the definition of development offered here, particularly if growth is subject to long waves. One pragmatic view is that when the "sustainable" growth rate changes for a period longer than the time horizon of policy makers, we say it is long run and that development has occured. Using this notion, long waves are part of the development process.

${ }^{7}$ Mancur Olson (1988) uses his well known theory of the corrosive effects of redistributive coalitions to explain the productivity decline after the mid 1960s. For a summary of the other studies on the determinants of the productivity decline see Wolff (1985).

The intent of the evidence presented in this paper is to be suggestive of the path of U.S. development. Empirical issues related to the measurement of the long term rate of growth and changes in the income distribution cannot be explored in depth in this paper.

'An expanded version of this model using quarterly data shows some evidence of a downward trend in productivity. This holds for sub-periods (e.g., 1950-1973) as well as the entire sample. The trend coefficient in the expanded model, like that reported here in regression 1 , is significant at only the .20 level. The presistence of this result suggests caution in accepting our conclusion that the growth measure suggests a single period of development.

${ }^{10} \mathrm{Flammang}(1989)$ refers to rising unemployment as a potential "softener" associated with niche changing. Changing niches may cause an increase in unemployment, but there is no necessary connection between the two. It is important to distinguish between rising unemployment that is a product of the business cycle and that caused by economic realignment due to niche changing.

${ }^{11}$ An obvious, but empirically controversial, example of development is Mancur Olson's (1982) theory that redistributive coalitions accumulate during periods of political stability and can slow the rate of economic growth. This well trod intellectual terrain is not discussed here. For a recent study lending support 
for the Olson hypothesis see Rasmussen and Zuehlke (1989).

${ }^{12}$ Even if technical change did not change the product mix to be more polluting, economic growth would inevitably increase enviromental degradation unless the pollution content of a unit of output falls faster than the units of output increase over time.

${ }^{13} \mathrm{~A}$ change in the distribution of income is expected if the environmental regulations affect certain types of employment. For example, many studies show that manufacturing jobs tend to offer relatively high wages to modestly skilled people and therefore tend to generate a more equal distribution of earnings. If the manufacturing sector is put at a competitive disadvantage due to the rising environmental niche, we would expect a rise in earnings inequality.

${ }^{14}$ Public health and communicable disease control are two important sources of increased life expectancy in relatively poor countries. As a nation grows more affluent the sources of incremental health benefits become increasingly private and beyond the financial reach of poor households.

${ }^{15}$ It is important to note that transfers in-kind are not usually measured in the income distribution, an obvious shortcoming in method of measurement. However, there is a misguided tendency to count in-kind medical transfers as income when trying to determine the number of households in poverty. In the extreme, consider a family with zero money income that has a member receive expensive medical care. The family still has zero spendable income but has "income" sufficient to put it above the poverty level. Many medical expenditures are complementary, not substitutes, for other spending. This is most obvious in the case of life sustaining medical expenditures.

${ }^{16}$ The role of public policy must also be considered in this context. Suppose some factor, say emerging international competition, lowers the long term growth path. If a policy response can be forthcoming that offsets this tendency with no impact on the income distribution, we would say development has not occured.

${ }^{17}$ Economists, by virtue of their emphasis on partial equilibrium analysis, have a tendency to eschew the domain of development in favor of more managable topics that are less likely to involve structural change. The tools of formal economic analysis lose much of their power when the problem involves structural change in the system.

\section{References}

Amos, Orley M., Jr. 1989. "Growth Pole Cycles: A Synthesis of Growth Pole and Long Wave Theories", The Review of Regional Studies, Vol 20 (1).

Baumol, Wiiliam J., 1986. "Productivity Growth, Convergence, and Welfare: What the Long Run Data Show," American Economic Review, December, 1072-1085.
Blackburn, McKinley and David Bloom 1987. "Earnings and Income Inequality in the United States," Population and Development Review, Vol 13, December, 575-589.

Dooley, Martin D. and Peter Gottschalk, 1984. "Earnings Inequality Among Males in the United States: Trends and the Effect of Labor Force Growth, "Joumal of Political Economy. 92:59-89.

Flammang, Robert A. 1979. "Economic Growth and Economic Development: Counterparts or Competitors?", Economic Development and Cultural Change, 28: 47-61. 1989. "Development and Growth Revisited", The Review of Regional Studies, Vol. 20 (1).

Henle, Peter and Paul Ryscavage, 1980. "The Diastribution of Earned Income Among Men and Women, 1958-77," Monthly Labor Review, April.

Kuznets, Simon, 1955. "Economic Growth and Income Inequaltiy," American Economic Review, March, 45:1-28.

Malazia, Emil E., 1989. "Economic Growth and Economic Development: Concepts and Measures", The Review of Regional Studies, Vol. 20 (1).

Medhoff, James L.,1984. "The Structure of Hourly Earnings Among U.S. Private Sector Employees: 1973-1984," manuscript.

Olson, Mancur, 1982. The Rise and Decline of Nations: Economic Growth, Stagflation, and Social Rigidities, New Haven: Yale University Press.

Olson, Mancur, 1983. "The South Shall Fall Again: The South as Leader and Laggard in Economic Growth," Southern Economic Journal, 49:917-932.

Olson, Mancur, 1988. "The Productivity Slowdown, the Oil Shocks, and the Real Cycle," Journal of Economic Perspectives, Vol 2, No. 4, 43-70.

Rasmussen, David W. and Allen Zeman, 1988. Trends in Male Earnings Inequality, 1969-1982, manuscript, 1988.

. and Thomas W. Zuehlke, 1989. "Sclerosis, Convergence and Taxes: Determinants of Growth Among the American States", Government and Policy, Vol. 8, No. 1 1990.

and Iljoong Kim, 1989. "Labor Productivity in the U.S.: Cyclical Factors and Secular Decline", manuscript, 1989.

Rostow, Walt W., 1961. Stages of Economic Growth, Cambridge: Cambridge University Press.

Sen, Amartya, 1983. “Development: Which Way Now?", The Economic Journal, December.

Wolff, Edward N., 1985. "The Magnitude and Causes of the Recent Productivity Slowdown in the United States: A Survey of Recent Studies," in William J. Baumol and Kenneth McLennan, editors, Productivity Growth and U.S. Competitiveness, New York: Oxford University Press. 